\title{
Vertical migration from surface soils to groundwater and source appointment of polycyclic aromatic hydrocarbons in epikarst spring systems, southwest China
}

Article

Accepted Version

Sun, Y., Zhang, S., Lan, J., Xie, Z., Pu, J., Yuan, D., Yang, H. and Xing, B. (2019) Vertical migration from surface soils to groundwater and source appointment of polycyclic aromatic hydrocarbons in epikarst spring systems, southwest China. Chemosphere, 230. pp. 616-627. ISSN 0045-6535 doi: https://doi.org/10.1016/j.chemosphere.2019.05.007 Available at https://centaur.reading.ac.uk/84102/

It is advisable to refer to the publisher's version if you intend to cite from the work. See Guidance on citing.

To link to this article DOI: http://dx.doi.org/10.1016/j.chemosphere.2019.05.007

Publisher: Elsevier

All outputs in CentAUR are protected by Intellectual Property Rights law, including copyright law. Copyright and IPR is retained by the creators or other copyright holders. Terms and conditions for use of this material are defined in the End User Agreement. 


\section{www.reading.ac.uk/centaur}

\section{CentAUR}

Central Archive at the University of Reading

Reading's research outputs online 


\section{Vertical migration from surface soils to groundwater and source appointment of polycyclic aromatic hydrocarbons in epikarst spring systems, southwest China}

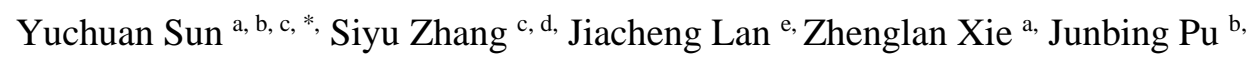

Daoxian Yuan ${ }^{\text {a, b, }}$ Hong Yang a, f, g, Baoshan Xing ${ }^{c}$

a Chongqing Key Laboratory of Karst Environment, School of Geographical Sciences; Southwest University, Chongqing, 400715, China

b Karst Dynamics Laboratory, Ministry of Land and Resources, Institute of Karst Geology, Guilin, 541004, China

c Stockbridge School of Agriculture, University of Massachusetts, Amherst, MA, 01003, United States

d Key Laboratory of Pollution Ecology and Environmental Engineering, Institute of Applied Ecology Chinese Academy of Sciences, Shenyang, 110016, China

e School of Karst Science, Guizhou Normal University/State Engineering Technology Institute for Karst Desertification Control, Guiyang, 550001, China

f Collaborative Innovation Center of Atmospheric Environment and Equipment Technology, Jiangsu Key Laboratory of Atmospheric Environment Monitoring and Pollution Control, School of Environmental Science and Engineering, Nanjing University of Information Science \& Technology, 219 Ningliu Road, Nanjing, 210044, China

g Department of Geography and Environmental Science, University of Reading, Whiteknights, Reading, RG6 6AB, UK

* Corresponding author. Chongqing Key Laboratory of Karst Environment, School of Geographical Sciences, Southwest University, Chongqing, 400715, China. E-mail address: sunyc@swu.edu.cn (Y. Sun).

\section{Abstract}

Understanding the transfer process of polycyclic aromatic hydrocarbons (PAHs) in the karst terrain is of great importance to their ecological risk assessments, however, the impact of the vertical transfer of the soil PAHs on the underground water is largely unknown in the karst system. Here, the vertical distribution and the seasonal variation of 16 PAHs in the soils and the water of 4 epikarst spring catchments in Southwest China were investigated. The total concentration of the PAHs ranged within $61-3285 \mathrm{ng} \mathrm{g}^{-1}$ in the soils, and $341-4969 \mathrm{ng} \mathrm{L}^{-1}$ in the spring water. The vertical distribution of the PAHs in soils varied with ring numbers and altitude of the catchment. PAHs concentrations were linearly related with the total organic carbon (TOC) at different depths in the catchments 563-783m above the sea level (A.S.L.). However, no correlation with TOC was observed in the catchment of a high altitude $(2090 \mathrm{~m}$ A.S.L.), because the large water flux led to the fast migration of the 2-3 rings PAHs in soils. The PAHs in soils and springs were mainly derived from the combustion of grass/wood/coal, closely related with the primary fossil fuels used in this area. This study demonstrate that the groundwater was heavily polluted by PAHs in the karst terrains of Southwest China, due to the vertical transfer of PAHs from the surface soils, and effective protection was urgently needed. 


\section{Introduction}

Polycyclic aromatic hydrocarbons (PAHs) have attracted scientific and public concerns for decades because of high ecological risks (Li et al., 2005; Chrysikou and Samara, 2009; Chen et al., 2011). The U.S. Environmental Protection Agency (USEPA) classified 16 PAHs as priority pollutants, among which 7 were potential carcinogens to humans (Ball and Truskewycz, 2013). The incomplete combustion of fossil fuels and biomass materials is the main anthropogenic source of PAHs in the environment. Once released into soils or groundwater, PAHs degrade slowly and show environmental persistence (Zhang et al., 2006; Schwarz et al., 2011), and thus may cause long-term exposure risks to terrestrial or aquatic organisms (Ball and Truskewycz, 2013).

Soils act as the major reservoir of PAHs due to the strong sorption property and high holding capacity (Bogan and Sullivan, 2003; Li et al., 2010). The vertical distribution of PAHs in soil is subjected to various processes (He et al., 2009), including the diffusion in air and water phases, advection via percolating water, vertical transfer via macropores, and chemical degradation (Heemken et al., 2000). These processes are influenced by the interaction of PAHs with soil organic matters (SOM). Due to the low degradability and high hydrophobicity, most of the PAHs can stay in SOM in the surface layer for many years (Chefetz et al., 2000; Ping et al., 2007) and only a small portion enters into the subsoil with the leaching of dissolved organic matters (DOM) and colloids (Cousins et al., 1999).

However, the vertical distribution pattern of the PAHs may be significantly different in the karst soils, because of the presence of the thin surface layer soils and the enormous interconnected fissures in karst system, which means the poor filtration and prepurification for pollutants (Yuan, 2000). Thus, the PAHs tend to move down faster in the karst soils than in other types of soils, and cause unanticipated pollution of the karst groundwater. However, karst groundwater is an important source, which supplies approximate $25 \%$ of the world population (Ford and Williams, 2007). Nevertheless, some karst systems can effectively retain PAHs in the soil, for example in a south German karst system (Schwarz et al., 2011), and their risks to the underground water were largely reduced. The karst Tiankeng system is a trap for PAHs, especially for high molecular weight PAHs (Oramah et al., 2008; Kong et al., 2015), and the knowledge on the contamination characteristics of PAHs in this system is of great significance for understanding their ecological and environmental risks.

Karst environments cover over 30\% of Chinese land areas (Yuan et al., 1994).

Concentrations, distribution, and sources of PAHs in topsoil, suspended solids, underground water, and sediments have been studied in two karst systems, Laolongdong (Lan et al., 2016) and Guozhuang (Shao et al., 2014) in China. However, to the best of our knowledge, fewstudies have focused on the impact of soil PAHs on the groundwater in karst terrains. Here, we made efforts to improve the understanding on the pattern of the vertical migration of PAHs in the karst soils and their influence on the groundwater, taking the Nanchuan karst terrain, Southwest China, as an example. The objectives of this study were: (1) to reveal the factors controlling the vertical migration of PAHs in the karst soils; and (2) to analyze the response of epikarst spring water (the outcrop of karst groundwater) to the PAHs pollution in overlying soils.

\section{Materials and methods}

\subsection{Study areas}

The Nanchuan karst terrain is located in Chongqing Municipality, Southwest China (Fig. 1). It is primarily subtropical monsoonal climate with a annual mean precipitation of $1185 \mathrm{~mm}$ and mean air temperature of 16 _C. The rainy season starts from May to October, while the dry season lasts from November to April. The study area is located in the northwest of the 
Dalou Mountain, where allows the difference of the large altitude of the sampling area, as the altitude may influence the migration and the distribution of PAHs (Liu et al., 2005). Four epikarst spring catchments were selected as the study sites (Table 1), including Hougou (HG), Lanhuagou (LHG), Baishuwan (BSW), and Shuifang (SF) which are 563, 736, 783 and 2090 $\mathrm{m}$ A.S.L., respectively, ranging from lowland to mountainous areas.

\subsection{Sample collection}

\subsubsection{Soil samples}

Soil samples were collected from five sites (S1 S5) (Fig. 1 and Table 1) in October 2010. Sites S1, S2 and S5 were located at the HG, BSW and SF epikarst spring catchments, respectively. Sites S3 and S4 were located at the Masson pine forest land and a rice field, respectively, at the LHG epikarst spring catchment. At each site, three soil profiles were collected and divided based on the depth measured from the surface of the profiles with a ruler. The surface soil sample was taken from 0 to $2 \mathrm{~cm}$ in depth. Then, samples were collected each $10 \mathrm{~cm}$ from the top of the profile. At HG and BSW, the deepest soil samples were collected at 60 and $80 \mathrm{~cm}$ due to different depth of bedrocks, respectively. Soil profiles collected at SF and LHG (S3, S4 and S5 sites) were over $100 \mathrm{~cm}$. The soil samples from the same depth of the three profiles were mixed homogeneously. The concentrations reported for PAHs represent an average level of each sampling site.

For each sample, $200 \mathrm{~g}$ soils were gathered in glass bottles with airtight caps using a solventrinsed stainless steel spatula, and sealed. Loose decayed litters were removed before sampling. Pine litters collected at S2 and S3 sites were treated separately and analyzed for concentrations of the total 16 PAHs ( $\sum \mathrm{PAHs}$ ). All samples were transferred to the lab as soon as possible and stored at $-26^{\circ} \mathrm{C}$ environment until analyzed. 


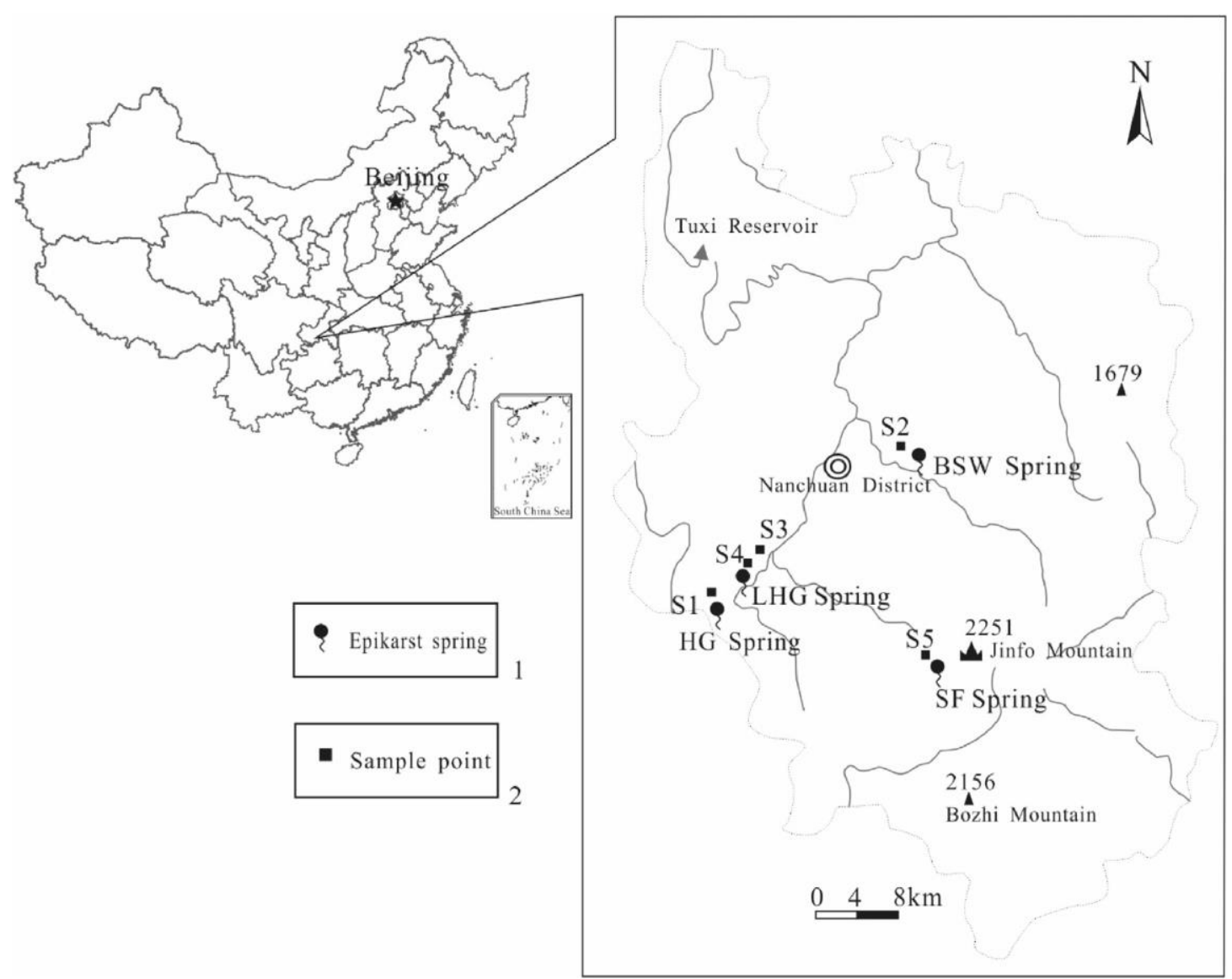

Fig. 1. Map of the sampling sites in Chongqing, Southwest China.

Table 1 Description of sampling sites.

\begin{tabular}{llllll}
\hline Epikarst spring & Altitude of spring outlet $(\mathrm{m})$ & Number of water sample & Soil profile in spring catchment & Depth of soil profile (cm) & Land-use of soil profile \\
\hline HG & 563 & 11 & $\mathrm{~S} 1$ & 60 & Maize field \\
BSW & 783 & 11 & $\mathrm{~S} 2$ & 80 & Woodland \\
LHG & 736 & $\mathrm{~S} 3$ & 100 & Woodland \\
& & $\mathrm{S} 4$ & 100 & Rice field \\
SF & & $\mathrm{S} 5$ & 100 & Grassland \\
\hline
\end{tabular}

\subsubsection{Water samples}

The spring water was collected monthly from October 2010 to October 2011 with pre-cleaned $1.25 \mathrm{~L}$ brown glass containers with airtight caps. The samples were stored at $4{ }^{\circ} \mathrm{C}$, and analyzed within three days.

\subsection{Chemicals and reagents}

The 16 priority PAHs monitored in this study included: naphthalene (Nap), acenaphthylene (Acy), acenaphthene (Ace), fluorene (Flu), phenanthrene (Phe), anthracene (Ant),

fluoranthene (Fla), pyrene (Pyr), chrysene (Chry), benzo(a)anthracene (BaA), benzo(k)

fluoranthene $(\mathrm{BkF})$, benzo(b)fluoranthene $(\mathrm{BbF})$, benzo(a)pyrene $(\mathrm{BaP})$,

dibenzo(a,h)anthracene (DaA), and indeno(1,2,3-cd)pyrene (InP). A mixed stock standard of the 16 PAHs was purchased from Dr. Ehrenstorfer GmbH Inc., Germany. A deuterated PAHs surrogate standard (naphthalene-d8, acenaphthene-d10, phenanthrene-d10, chrysene-d12, perylene-d12), and a PAHs internal standard (hexamehylbenzene) were purchased from the Supelco, USA. Working standard solutions containing PAHs and deuterated PAHs mixtures 
were prepared by diluting the stock solutions in n-hexane. All solutions were stored at $-26{ }^{\circ} \mathrm{C}$ until use. All solvents used for the extraction and cleanup procedures were HPLC grade and obtained from Fisher Scientific (Fair Lawn, NJ, USA). Deionized water was produced by a Milli-Q system (Simplicity, Millipore Co, Molsheim, France). Glass fiber filters were heated at $450{ }^{\circ} \mathrm{C}$ for $4 \mathrm{~h}$ and anhydrous sodium sulfate $\left(\mathrm{Na}_{2} \mathrm{SO}_{4}\right)$ were heated at $550{ }^{\circ} \mathrm{C}$ for $8 \mathrm{~h}$ to remove organic residuals.

\subsection{Sample treatment}

Soil samples were freeze-dried and meshed. Each sample ( 80 mesh, $10 \mathrm{~g}$ ) mixed thoroughly with an equal amount of anhydrous $\mathrm{Na}_{2} \mathrm{SO}_{4}$ and $2 \mathrm{~g}$ activated copper powder was extracted by an accelerated solvent extractor (ASE 350) (Lu et al., 2012). Samples and blanks were spiked with a recovery standard solution containing 5 deuterated PAH congeners. All samples were extracted with n-hexane/dichloromethane (DCM) $(1: 1, \mathrm{~V} / \mathrm{V})$. The cells were filled with solvent, pressurized to $1500 \mathrm{psi}$, and heated to $125^{\circ} \mathrm{C}$ within $6 \mathrm{~min}$. Pressure and heat were held for $5 \mathrm{~min}$ (static extraction), followed by rinsing with more solvent (60\% of cell volume) and purging with $\mathrm{N}_{2}$ for $90 \mathrm{~s}$.

Water samples $(1.0 \mathrm{~L})$ were filtered through $0.7 \mathrm{~mm}$ glass fiber filter membranes under vacuum. The filtrates were added with a measured volume of a surrogate standard mixture containing 5 deuterated PAH congeners, and then were extracted using an automatic solidphase extraction system (SPE-DEX 4790). Before loading samples, the disk (C18) was first conditioned with ethyl acetate and methanol to remove air and leach impurity, respectively, and then with ultrapure water to equilibrate the phase. A water sample was then loaded. Afterwards, the disk was air-dried for $10 \mathrm{~min}$ to remove the residual water. The disks were eluted by acetone and DCM. The effluents were collected into a $50 \mathrm{~mL}$ pearshaped flask.

The effluents were dried with anhydrous granular $\mathrm{Na}_{2} \mathrm{SO}_{4}$, and concentrated to approximately $2 \mathrm{~mL}$. The concentrates were purified by aluminum oxides and silica gel column chromatography. The cartridge was then eluted with $15 \mathrm{~mL}$ n-hexane/DCM $(3: 2, \mathrm{v} / \mathrm{v})$ to obtain PAHs. Effluents were transferred into double-layered silicone- Teflon septum vials and further concentrated to $0.2 \mathrm{~mL}$ under the gentle steam of pure nitrogen gas.

\subsection{Instrumental analysis}

PAHs were analyzed using an Agilent 7890A gas chromatograph equipped with a 5975C mass selective detector and a HP-5MS capillary column $(30 \mathrm{~m}, 0.25 \mathrm{~mm}$ i.d., $0.25 \mathrm{~mm}$ film thickness). High purity (99.999\%) helium was used as the carrier gas. Temperatures of the injector, the quadrupole, the ion source and the transfer line were set at 290, 150, 230 and 290 ${ }^{\circ} \mathrm{C}$, respectively. The oven temperature was maintained at $60 \_\mathrm{C}$ for $1 \mathrm{~min}$, then boosted to $160{ }^{\circ} \mathrm{C}$ at $10^{\circ} \mathrm{C} \mathrm{min}^{-1}$, and finally increased to $290{ }^{\circ} \mathrm{C}$ at $8^{\circ} \mathrm{C} \mathrm{min}-{ }^{-1}$, and maintained for 10 min. The quantification of samples was performed by a seven-point calibration curve $\left(\mathrm{R}^{2}=\right.$ 0.999-0.9999.) for each individual component.

\subsection{Quality control and quality assurance}

Laboratory quality control procedures included the analysis of method blanks (solvent), spiked blanks (standards spiked into solvent), matrix spikes/matrix spike duplicates, and sample duplicates. No interference was observed in the blanks. The stability and responses of the instrument were checked by using the NIST (2008) standard solution (SRM No 1647c). The instrument was calibrated every day with calibration standards. The duplicate analysis of selected specimens showed a coefficient of variation lower than $15 \%$. Recoveries for surrogate standards were $70 \pm 5 \%, 80 \pm 5.6 \%, 92 \pm 7.5 \%, 95 \pm 12 \%, 96 \pm 8.5 \%$ for naphthalene-d8, acenaphthened 10, phenanthrene-d10, for chrysene-d12, and perylene-d12, respectively. Limit of detection of $10 \mathrm{~g}$ solid samples averaged $0.5-3.1 \mathrm{ng} / \mathrm{g}$ dry weights and varied from 0.2 to $1.5 \mathrm{ng} / \mathrm{L}$ for the $1 \mathrm{~L}$ water samples. 


\subsection{Soil characterization}

The soils were characterized by conventional standard procedures: the soil organic carbon was measured by total organic carbon (TOC) analyzer (JENA 3100 TOC meter). The pH was determined by dissolving the soils in $1 \mathrm{M} \mathrm{KCl}$ (soil: solution ratio=1:2.5) and by potentiometric glass electrodes. Soil water contents were defined as the mass difference before and after oven drying at $110 \_$C. Clay contents were analyzed by laser particle diameter analyzer (Mastersizer 3000).

\subsection{Statistics analysis}

Multiple regression and Pearson correlation analysis was performed using the SPSS 13 statistical software package (SPSS Inc., Chicago, IL). The significance level was set at $\mathrm{p}<$ 0.05 .

\section{Results and discussion}

\subsection{Vertical distribution and compositions of PAHs in soils}

All the 16 PAHs were detected at each sampling site. The concentrations varied from 161 to $3285 \mathrm{ng} \mathrm{g}^{-1}$, with a mean value of $987 \mathrm{ng} \mathrm{g}^{-1}$. The concentrations in the surface horizon ranged from $806 \mathrm{ng}$ g_ 1 at $\mathrm{S} 4$ to $3101 \mathrm{ng} \mathrm{g}_{-} 1$ at S1. Vertical distribution profiles for $\sum \mathrm{PAHs}$ followed three patterns (Fig. 2): (1) Sites S1 and S4 were significantly influenced by tillage patterns or human activities (Table 1). At the two sites, the PAHs concentrations reached a peak at $10 \mathrm{~cm}$. At $\mathrm{S} 1$, the concentration dropped rapidly to a minimum at $40 \mathrm{~cm}$. At S4, a second peak (687 $\left.\mathrm{ng} \mathrm{g}^{-1}\right)$ appeared at $50 \mathrm{~cm}$, and then the concentration dropped rapidly; (2) S2 and S3 collected from the Masson pine forest land showed a similar pattern along the soil genetic horizons. PAHs mostly appeared in the surface layer. The concentration decreased sharply at $10 \mathrm{~cm}$, and then varied slightly; (3) At S5, the peak concentration (2575 $\left.\mathrm{ng} \mathrm{g}^{-1}\right)$ did not appear until $40 \mathrm{~cm}$, followed by a sharp decrease with a minimum occurring at $60 \mathrm{~cm}$.

The vegetation cover was inferred as the most important factor influencing the concentration of PAHs in the upper layer soils. The peak concentrations of PAHs appeared in the top 0-2 $\mathrm{cm}$ soil layer at sites $\mathrm{S} 2$ and S3, because pine litters rich in PAHs ( $\sum$ PAHs of pine litters: $2813 \mathrm{ng} \mathrm{g}^{-1}$ at S2 and $3299 \mathrm{ng} \mathrm{g}^{-1}$ at S3) continuously released the pollutants to the soils, and the thick Masson pine litter layers protected PAHs from photodegradation and evaporation (Cousins et al., 1999). At other sites, for example S1 and S4 (without the litter layer on the top layer), PAHs in the top layer were sensitive to photodegradation or evaporation without the protection of the litter layer (Tian et al., 2008).

The compacted horizon played an important role in slowing down the transport of PAHs to sublayer soils at S2 and S3, resulting in most PAHs being retained in the top layers (He et al., 2009). At S1 and S4, the soils were much less compacted due to human activities, thus allowing fast downward transport of PAHs. Tillage activities and irrigation further facilitated the downward transport of PAHs. This was typical at S4, where the second concentration peak appeared at $50 \mathrm{~cm}$, because paddy soils were irrigated, soaked, and drained for about 6 months each year, leading to a marked leaching of PAHs.

Generally, the concentration of PAHs decreased along the depth due to low mobility (Wang et al., 2001; Li et al., 2010). As observed at S1 S4, the concentration of PAHs in the surface 0$10 \mathrm{~cm}$ soils was much higher than that in deep soils (Fig. 2), because the input of PAHs to surface soilswas faster than the downward transport (He et al., 2009). But at S5, PAHs in the 0-10 cm layer was much less than that in the $30-50 \mathrm{~cm}$ layer (Fig. 2), meaning that the downward transport of PAHs was fast (He et al., 2009). This was not only attributed to the loose soils, but also to a high percentage of low molecular weight PAHs at S5 (Fig. 2), 
indicating that the composition of PAHs may be one of key factors influencing the vertical distribution.

The mean percentages of 4 and 5-6 rings PAHs declined with the increase of the altitude, while 2-3 rings PAHs showed opposite trend (Fig. 2). Similar trends were found in the study of Liu et al. (2005). The percentage of 4 and 5-6 rings PAHs at S1 (563mA.S.L.) ranged within 44-70\%, of which the mean value was 62\%. At S5 (2090mA.S.L.), the mean percentage was $4.9 \%$. At S4 and S5, 2-3 rings PAHs contributed to $81 \%$ and $95 \%$ (mean value) of the $\sum$ PAHs for different layers, respectively, while at S1, the maximum percentage of 2-3 rings PAHs was less than 55\% (at $40 \mathrm{~cm}$ ). At S2 (736mA.S.L.) and S3 (783mA.S.L.), although 2-3 rings PAHs were dominated for all layers except for the top layer $(<40 \%)$, the mean contribution (81 and 77\%) was lower than that at S5. The typical altitude-dependent distribution of PAHs can be expected, as low molecular weight PAHs (2-3 rings) are easier to migrate to higher altitudes than high molecular weight PAHs (4, 5-6 rings) (Perugini et al., 2007). It is interesting that the percentage of 2-3 rings PAHs was remarkably high at different depths at S5 (Fig. 2). This was attributed to the low average local temperature $\left(8^{\circ} \mathrm{C}\right)$ beneficial to the deposition of the gaseous PAHs (2-3 rings), and to the loose soils allowing fast downward transport of the PAHs (He et al., 2009; Ma and Harrad, 2015). 

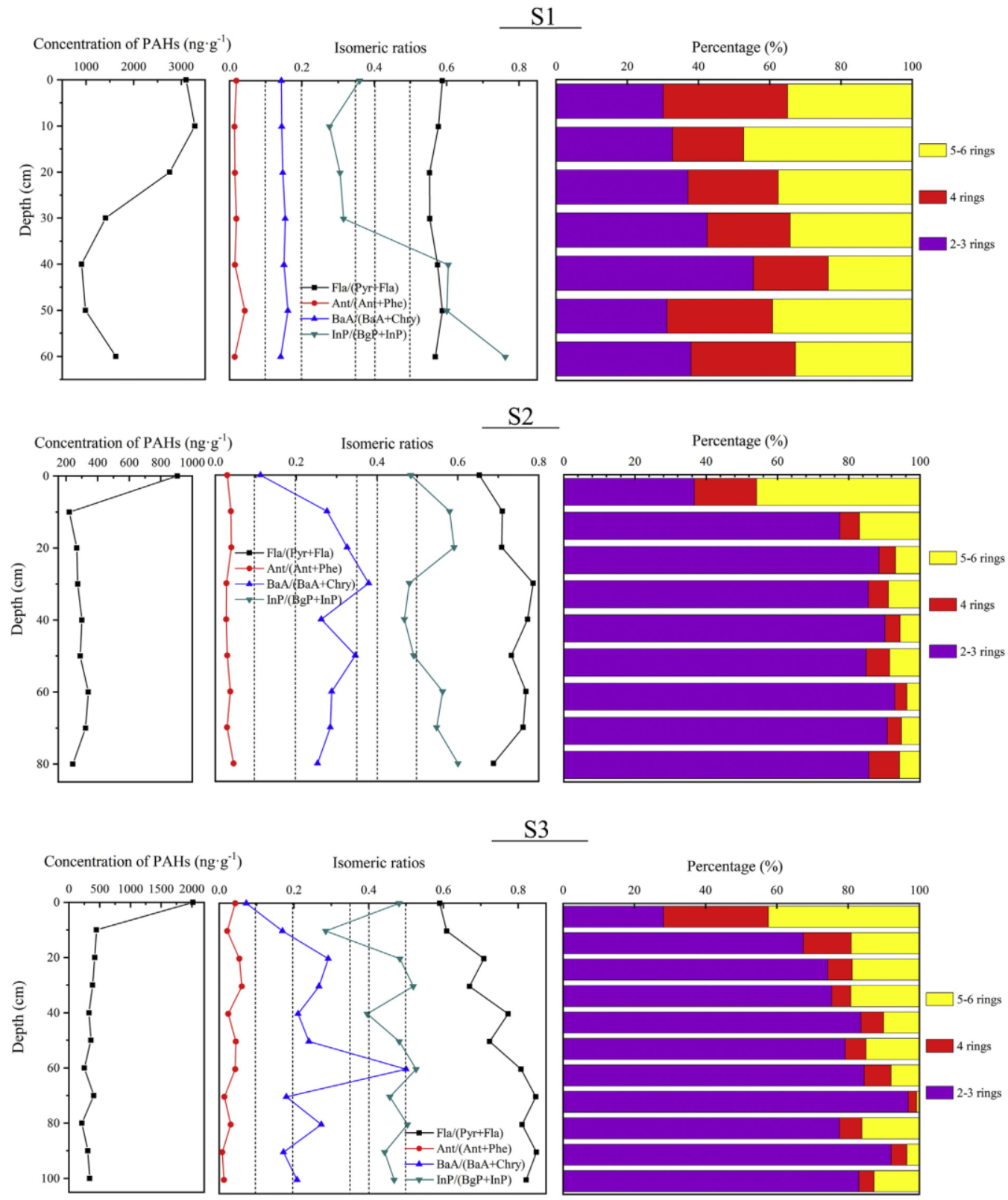

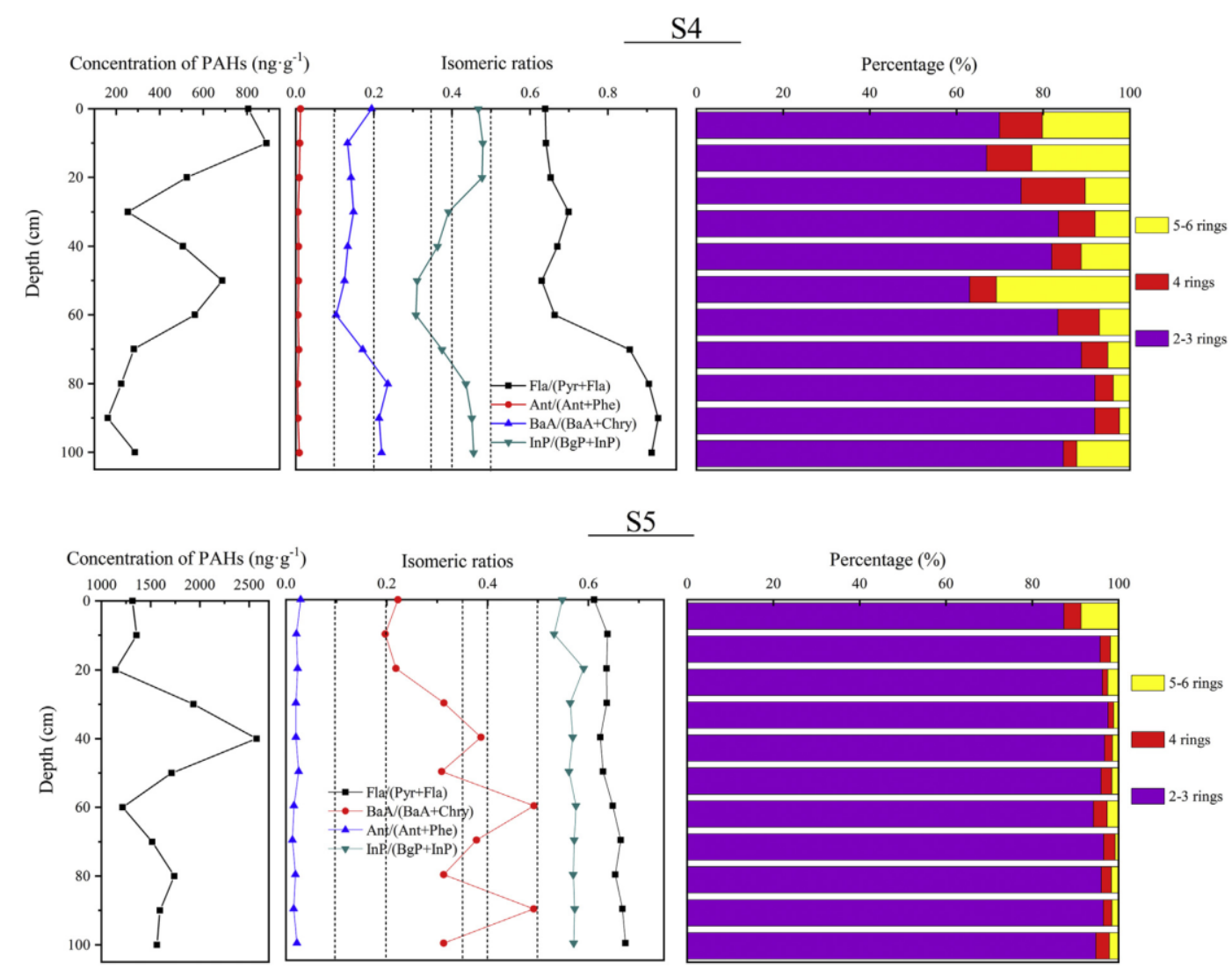

Fig. 2. Vertical profiles of total PAHs concentration $\left(\mathrm{ng} \mathrm{g}^{-1}\right)$, isometric ratios and

compositions in different soil profile. (Ant/(Ant + Phe) $<0.10$ indicates petroleum, and $>0.10$ indicates combustion; $\mathrm{BaA} /(\mathrm{BaA}+\mathrm{Chry})<0.4$ indicates petroleum source, $>0.35$ indicates combustion source, and $0.2<\mathrm{BaA} /(\mathrm{BaA}+\mathrm{Chry})<0.35$ indicates mixed sources; Fla/(Fla + $\mathrm{Pyr})<0.4$ indicates petroleum source, $>0.50$ indicates grass/wood/coal combustion source, and $0.4<\mathrm{Fla} /(\mathrm{Fla}+\mathrm{Pyr})<0.5$ indicates petroleum combustion source; $\mathrm{InP} /(\mathrm{InP}+\mathrm{BgP})<0.2$ indicates petroleum source, $>0.50$ indicates grass/wood/coal combustion source, and $0.2<$ $\mathrm{InP} /(\mathrm{InP}+\mathrm{BgP})<0.5$ indicates petroleum combustion (Yunker et al., 2002; Ohura et al., 2015).

\subsection{Variation and composition of PAHs in spring water}

Almost all the 16 PAHs were detected in each month in each epikarst spring (Table 2). Nap, Ace, Acy, Flu and Phe were the most abundant PAHs in all epikarst springs, contributing to 47-98\% of the $\sum$ PAHs. The mean concentrations of $\sum$ PAHs and 7 carcinogenic PAHs ( $\sum$ PAHscarc) were 1668, $178 \mathrm{ng} \mathrm{L}^{-1}$ at SF, 2135, $168 \mathrm{ng} \mathrm{L}^{-1}$ at $\mathrm{HG}, 1608,226 \mathrm{ng} \mathrm{L}^{-1}$ at LHG, and 1798, $332 \mathrm{ng} \mathrm{L}^{-1}$ at BSW, respectively (Table 2). The mean concentration of $\sum$ PAHs was the highest at HG, followed by BSW, SF, and LHG, while the order for $\sum$ PAHscarc was BSW > LHG > SF > HG. As an individual PAH, Flu exhibited the highest average concentration, $627 \mathrm{ng} \mathrm{L}^{-1}$ at HG. Comparing with other groundwater system, the levels of PAHs in this study area are much higher than those in reclaimed wastewater irrigation area (1943 $\mathrm{km}^{2}$, Northern China) (139.1-483.7 $\mathrm{ng} \mathrm{L}^{-1}$, mean value $\left.234.5 \mathrm{ng} \mathrm{L}^{-1}\right)$ (Li et al., 2012), seepage water (165 $\mathrm{km}^{2}$, Germany) (2-371 $\left.\mathrm{ng} \mathrm{L}^{-1}\right)$ (Schwarz et al., 2011), and Yellow River Delta (2200 km², Northern China) (8.51-402.84 $\mathrm{ng} \mathrm{L}^{-1}$, mean value $54.64 \mathrm{ng}$ $\left.\mathrm{L}^{-1}\right)$ ( $\mathrm{Li}$ and $\left.\mathrm{Li}, 2017\right)$, but were lower than that in Taihu plain $\left(34,475 \mathrm{~km}^{2}\right.$, Southern China) (4e32,449 $\mathrm{ng} \mathrm{L}^{-1}$, mean value $4420 \mathrm{ng} \mathrm{L}^{-1}$ ) (Cui et al., 2008) and Guozhuang karst water 
system (5600 km², China) (2137-9037 $\mathrm{ng} \mathrm{L}^{-1}$, mean value $5020 \mathrm{ng} \mathrm{L}^{-1}$ ) (Shao et al., 2014). This indicated that the groundwater in this study was contaminated with PAHs. As the epikarst spring water was the outcrop of karst groundwater, the high concentration and detection frequency of PAHs in the epikarst springwater implied that the thin soil layers had already lost the protective function for the groundwater.

$\sum$ PAHs and $\sum$ PAHscarc of the 4 springs exhibited different seasonal variations (Fig. 3). At $\mathrm{SF}$ and $\mathrm{HG}$, the concentration of $\sum \mathrm{PAHs}$ fluctuated greatly during the dry season from November 2010 to April 2011, and was relatively stable during the rainy season from May 2011 to September 2011. While at LHG and BSW, the seasonal variation of $\sum$ PAHs was completely opposite. At SF and HG, the average concentration of $\sum$ PAHs during the dry season (2066 and $2823 \mathrm{ng} \mathrm{L}^{-1}$, respectively) was much higher than that during the rainy season (1440 and $797 \mathrm{ng} \mathrm{L}^{-1}$, respectively). At LHG, the average concentrations of $\sum$ PAHs during the rainy season $\left(1619 \mathrm{ng} \mathrm{L}^{-1}\right)$ and the dry season $\left(1570 \mathrm{ng} \mathrm{L}^{-1}\right)$ were close. A possible reason was that rainfalls promoted soil permeability during the rainy season, and allowed PAHs in soils to be dissolved and migrated into groundwater, i.e. the dissolution effect (Yang et al., 2012). On the contrary, the intensive rainfalls can shorten the residence-time of water in the soils by activating the drainage system, and thus diluted PAHs in the spring water, i.e. the dilution effect (Yang et al., 2012; Jiang et al., 2013). At HG and SF, the dilution effect of rainwater was more dominant than the dissolution effect. At BSW, where the average concentration of $\sum$ PAHs during the rainy season $\left(2183 \mathrm{ng} \mathrm{L}^{-1}\right)$ was much higher than that during the dry season (1289 $\left.\mathrm{ng} \mathrm{L}^{-1}\right)$, the dissolution effect was prominent. This can be attributed to a better eco-environment at BSW spring catchment, where the regulating capacity of vegetation is stronger than that of other spring catchments. The strong regulating capacity of vegetation increased the residence-time of rainwater in the epikarst spring system to dissolve more soil PAHs.

The seasonal variations of $\sum$ PAHscarc were different from those of the $\sum$ PAHs (Fig. 3). The mean concentration of $\sum$ PAHscarc during the rainy season was higher than that during the dry season for each spring. This is because that the PAHscarc are 4-5 rings PAHs, which are difficult to migrate in soils during the dry season (Schwarz et al., 2011; Perrette et al., 2013). But during the rainy season, the increased soil moisture allowed abundant DOM and colloids dissolved by soil water to carry more PAHscarc into groundwater (Shevenell and McCarthy, 2002; Schwarz et al., 2011).

The annual average percentage was $72-79 \%$ for 2-3 rings PAHs, and less than $39 \%$ for 5-6 rings PAHs (Fig. 4). During the rainy season, the 2-3 rings PAHs decreased by $22-29 \%$ due to a remarkable dilution effect, while 5-6 rings PAHs increased from 5 to 6 to $15-19 \%$ due to the dissolution effect at SF, HG and LHG. This is different from the non-karst system, where low molecular weight PAHs were transferred to the groundwater, and high molecular weight PAHs were efficiently filtered by soils in forest (Perrette et al., 2013).

The increased soil permeability is responsible for the fast migration of the intrinsically hydrophobic 5-6 rings PAHs during the rainy season at SF, HG and LHG (Bandowe et al.,

2011). A large amount of DOC (Table 2) carrying 5-6 rings PAHs was flushed into the spring water due to the intensive rainfalls during the rainy season, while the DOC was low during the dry season, implying less 5-6 rings PAHs entered the springwater during the dry season. The seasonal variation was not very marked at BSW (Fig. 4). The strong storage capacity of the ecosystem resulted in high-soil permeability, and this allows the high-ring PAHs to migrate with DOM in soils during the dry season ( $\mathrm{Li}, 2009)$.

The percentages of 4 and 5-6 rings PAHs in SF spring water (the mean percentage: $21.8 \%$ ) were significantly higher than those in SF soil (the mean percentage: $4.8 \%$ ). A possible reason was that the pressure of spring water dropped at the outlet due to forming a turbulence flow (Jiang et al., 2013), which caused the strong volatilization of 2-3 rings PAHs and brought increases in 4 and 5-6 rings PAHs in spring water. The percentage of 4 and 5-6 rings PAHs increased most obviously at SF due to the largest flux in SF spring. 
Table 2 Composition and concentration of PAHs $\left(\mathrm{ng} \mathrm{L}^{-1}\right)$ and DOC $\left(\mathrm{mg} \mathrm{L}^{-1}\right)$ in epikarst springs.

\begin{tabular}{|c|c|c|c|c|c|c|c|c|}
\hline \multirow[t]{2}{*}{ Compounds } & \multicolumn{2}{|l|}{ HG Spring } & \multicolumn{2}{|c|}{ BSW Spring } & \multicolumn{2}{|l|}{ LHG Spring } & \multicolumn{2}{|l|}{ SF Spring } \\
\hline & Range & Mean & Range & Mean & Range & Mean & Range & Mean \\
\hline Nap & $67.2-2440$ & 579 & $89.9-622$ & 256 & $93.4-834$ & 332 & $81.6-2309$ & 500 \\
\hline Acy & $24.3-339$ & 147 & $28.8-281$ & 144 & $22.5-287$ & 144 & $28.1-1631$ & 257 \\
\hline Ace & $42.9-539.3$ & 184 & $59.2-270$ & 159 & $38.7-371$ & 170 & $63.7-573$ & 154 \\
\hline Flu & $74.8-4289$ & 627 & $78.1-970$ & 312 & $44.0-440$ & 250 & $88.5-535$ & 220 \\
\hline Phe & $23.4-1524$ & 253 & $30.9-980$ & 323 & $23.8-836$ & 266 & $29.4-467$ & 203 \\
\hline Ant & $3.3-176$ & 31.5 & $5.4-106$ & 42.7 & $4.2-97.8$ & 35.3 & $5.9-48.6$ & 23.2 \\
\hline Fla & $5.5-392$ & 70.9 & $10.9-288$ & 96.0 & $5.6-258$ & 81.4 & $8.3-140$ & 57.0 \\
\hline Pyr & $7.0-243$ & 46.8 & $9.2-184$ & 70.6 & $7.6-166$ & 53.0 & $9.7-89.5$ & 40.5 \\
\hline $\mathrm{BaA}^{*}$ & $3.4-54.0$ & 16.4 & $5.3-54.4$ & 33.1 & $4.4-50.6$ & 20.5 & $5.4-24.5$ & 15.4 \\
\hline Chry ${ }^{\circ}$ & $4.9-77.2$ & 23.5 & $8.5-140$ & 46.6 & $4.4-67.6$ & 25.0 & $6.8-42.0$ & 22.4 \\
\hline $\mathrm{BbF}^{*}$ & $3.2-55.9$ & 20.1 & $8.5-127$ & 44.2 & $3.7-59.5$ & 24.3 & $5.8-37.0$ & 19.6 \\
\hline $\mathrm{BkF}^{*}$ & $3.0-209$ & 31.1 & $4.9-137$ & 47.8 & $3.1-52.0$ & 23.0 & $5.1-25.1$ & 15.9 \\
\hline $\mathrm{BaP}^{*}$ & $3.5-54.8$ & 18.8 & $5.3-138$ & 37.4 & $3.7-59.0$ & 24.6 & $5.1-161$ & 34.4 \\
\hline $\operatorname{In} \mathrm{P}^{\circ}$ & $2.3-101$ & 30.0 & $4.9-129$ & 62.7 & $4.4-122$ & 54.5 & $5.2-92.8$ & 36.6 \\
\hline $\mathrm{DaA}^{*}$ & N.D 111 & 28.0 & $4.8-136$ & 60.2 & N.D 132 & 54.6 & N.D 92.6 & 34.0 \\
\hline $\mathrm{BgP}$ & $2.2-94.7$ & 27.7 & $4.6-165$ & 62.6 & $3.8-125$ & 50.1 & $5.0-81.8$ & 33.6 \\
\hline$\sum$ PAHs & $498-4968$ & 2135 & $627-3504$ & 1798 & $341-3193$ & 1608 & $842-4152$ & 1668 \\
\hline$\sum \mathrm{PAH}_{\text {scarc }}$ & $20.2-663$ & 168 & $37.9-792$ & 332 & $27.8-517$ & 226 & $39.0-322$ & 178 \\
\hline \multirow[t]{2}{*}{ DOC } & $0.09-1.1$ & 0.3 (DS) & $0.2-3.6$ & 2.4 (DS) & $0.3-2.2$ & 0.7 (DS) & $2.3-6.4$ & 3.3 (DS) \\
\hline & $0.8-2.6$ & 1.6 (RS) & $1.2-5.8$ & 2.9 (RS) & $1.6-4.9$ & 3.2 (RS) & $4.6-8.1$ & 5.4 (RS) \\
\hline
\end{tabular}

Note: 1)* stands for carcinogenic PAHs; PAH sare stands for 7 carcinogenic PAHs; N.D stands for below the detection limit.; DS stands for dry season; RS stands for rainy season.

\subsection{Factors influencing the migration of PAHs in soils}

In order to unveil soil characteristics influencing the vertical migration of PAHs, the relationship between TOC, soil water contents, $\mathrm{pH}$, and clay contents (Fig. 5) with the concentrations of $\sum$ PAHs were analyzed by using the multiple regression analysis. The concentrations of $\sum$ PAHs exhibited a good linear relation with TOC $(\mathrm{p}<0.05$, within the $95 \%$ confidence interval) at the sites $\mathrm{S} 1\left(\mathrm{R}^{2}=0.880\right), \mathrm{S} 2\left(\mathrm{R}^{2}=0.965\right), \mathrm{S} 3\left(\mathrm{R}^{2}=0.995\right)$ and $\mathrm{S} 4$ $\left(\mathrm{R}^{2}=0.843\right)$. Thus, it can be inferred that PAHs at these sites were strongly adsorbed by SOM, and thus the vertical migration of PAHs was significantly influenced by TOC. For S5, no main factors were observed by the multiple regression analysis, indicating that PAHs were easy to migrate vertically in this catchment (Levy et al., 2017). The migration of PAHs in soils was greatly affected by TOC, soil structures and textures, and land use types or farming patterns (Krauss et al., 2000; He et al., 2009). Due to the hydrophobicity and nonpolarity, PAHs mainly combined with SOM or humus colloids in soils (Weigand et al., 1998; Chefetz et al., 2000; Bogan and Sullivan, 2003). Thus, SOM played as carriers of PAHs for downward migration (Krauss et al., 2000; Zhang et al., 2006) and protected PAHs from the degradation. The adsorption of PAHs on SOM was affected by soil $\mathrm{pH}$, which can alter the amounts of hydrophobic regions in SOM, and can lead to coagulation by forming intramolecular hydrogen bond (Raber et al., 1998). Clays of finer particles had larger specific surface area and more adsorption sites (Soren and Gerhard, 2002), and showed higher sorption capacity to PAHs than the fine or coarse sands (Maruya et al., 1996). The influence of water content on vertical migration of PAHs cannot be neglected, as low hydrophobicity PAHs can migrate or diffuse with the seepage water in soils (Schwarz et al., 2011). But water molecules may compete with PAHs for the adsorption sites on soil colloids (Knabner et al., 1996), hinder binding of PAHs with SOM and facilitate the downward migration with moving water.

The annual average discharge of the spring waters was 0.05 (HG), 0.48 (LHG), 1.2 (BSW) and $6.3 \mathrm{~L} \mathrm{~s}^{-1}$ (SF) (Jiang et al., 2013; Li, 2009). Therefore, the corresponding annual average flux of PAHs were 106 (HG), 771(LHG), 2157 (BSW) and 10,508 $\mathrm{ng} \mathrm{s}^{-1}$ (SF). The annual average flux of PAHs in the SF spring (site S5) was much higher than that in other springs. This was in line with the multiple regression analysis results that the soils at S5 were low in the content of clays and thus PAHs were easy to migrate into the underground water.

Although the concentration of PPAHs in soils at S1 was the highest among all sites, the annual average flux of PAHs in the HG spring at $\mathrm{S} 1$ was the lowest. This was because that the TOC at S1 was higher than those at other sites (Fig. 5). This indicated that TOC increase in soil could prohibit the migration of PAHs in soil when the TOC was the key factor controlling the vertical migration in soil profiles. Although the soil water content was not regarded as the 
key factor influencing vertical migration of PAHs at S1, the obvious low soil water content at this site (Fig. 5) may still, to a certain extent, contribute to the low annual average flux of PAHs, due to few water molecules competing with PAHs to adsorb on the SOM.
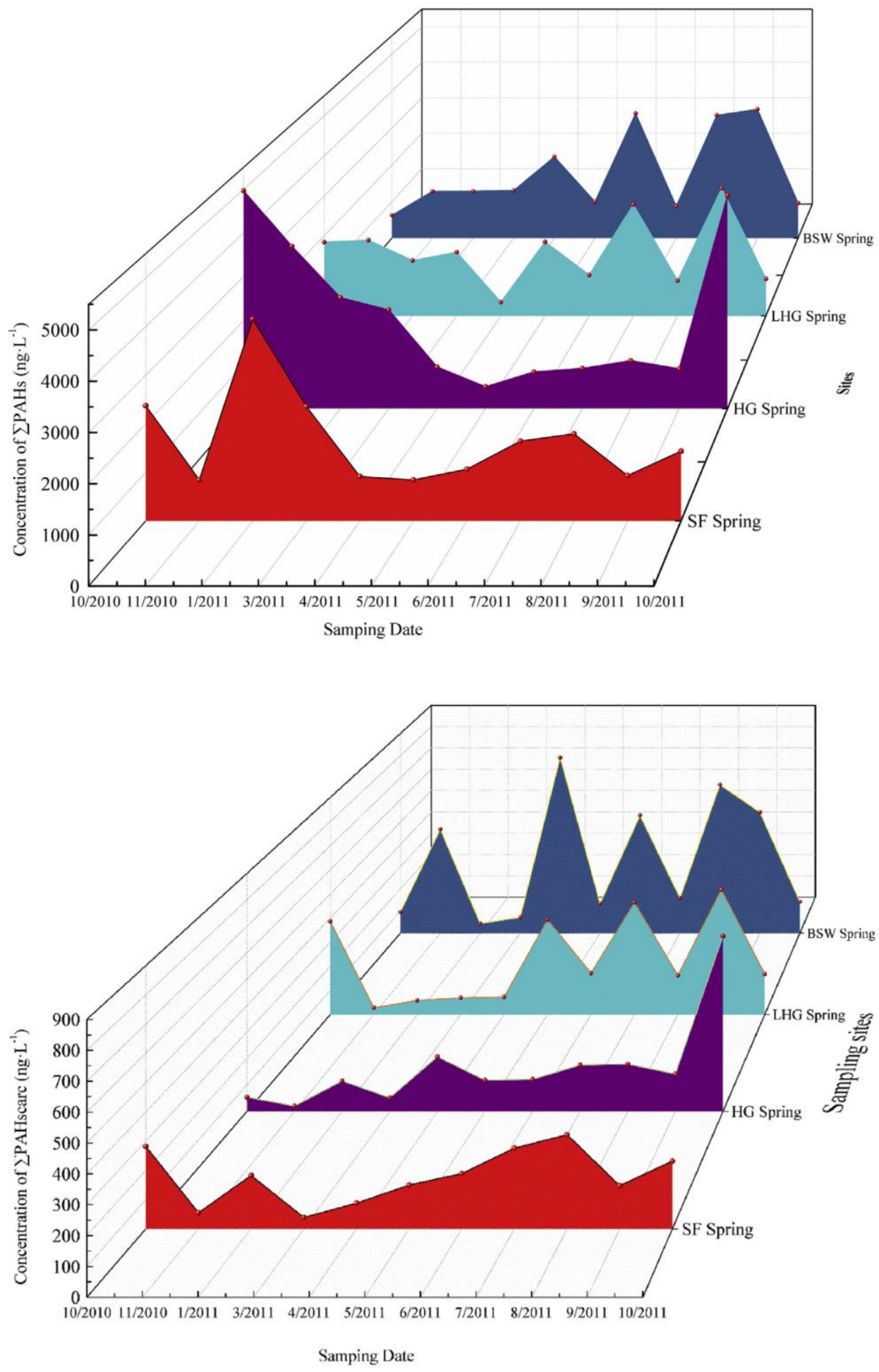

Fig. 3. Variation of total PAHs and PAHscarc concentration $\left(\mathrm{ng} \mathrm{L}^{-1}\right)$, isometric ratios and compositions in water samples from four springs. 

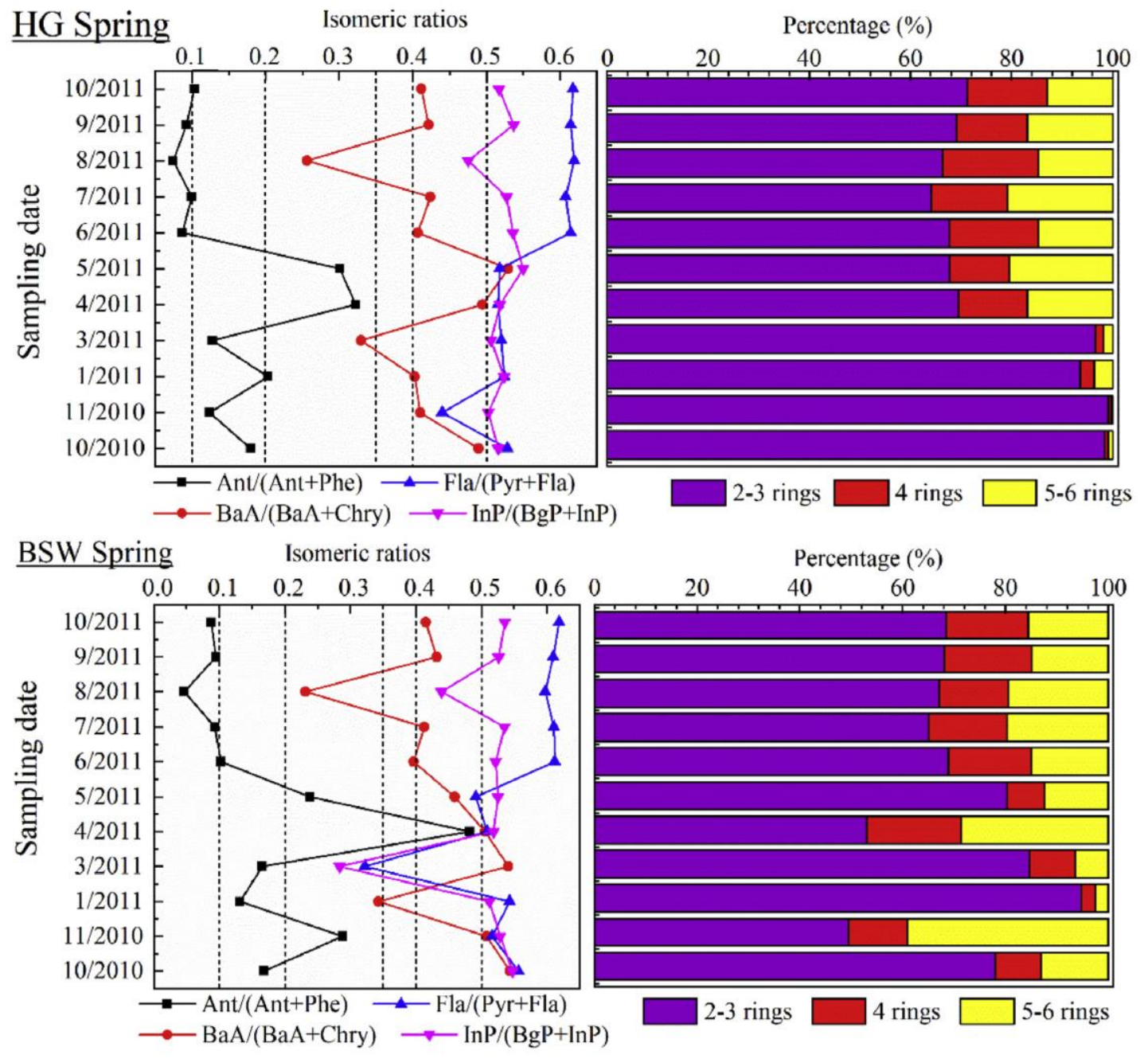

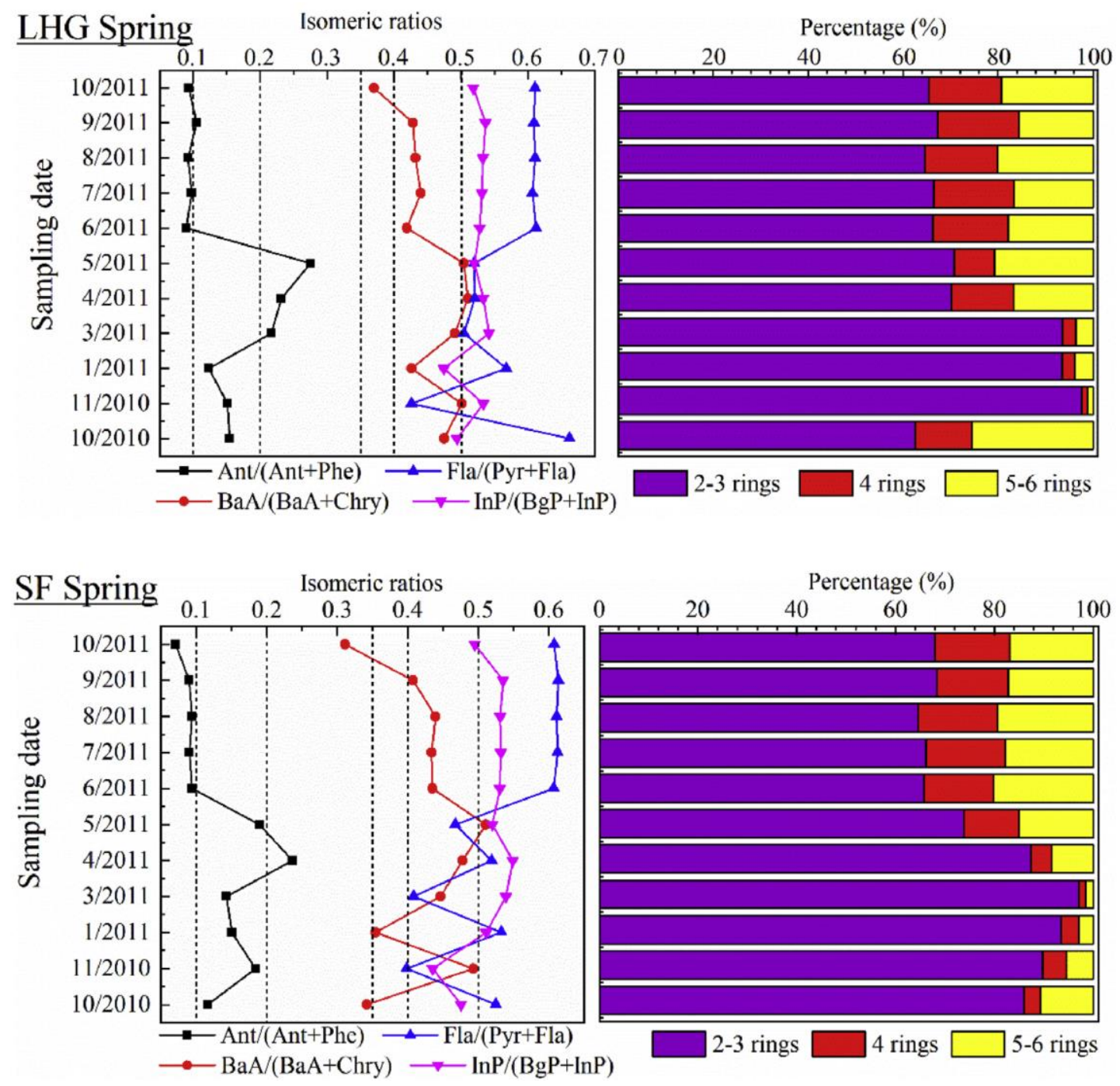

Fig. 4. Variation of isometric ratios and compositions in water samples from four springs. 

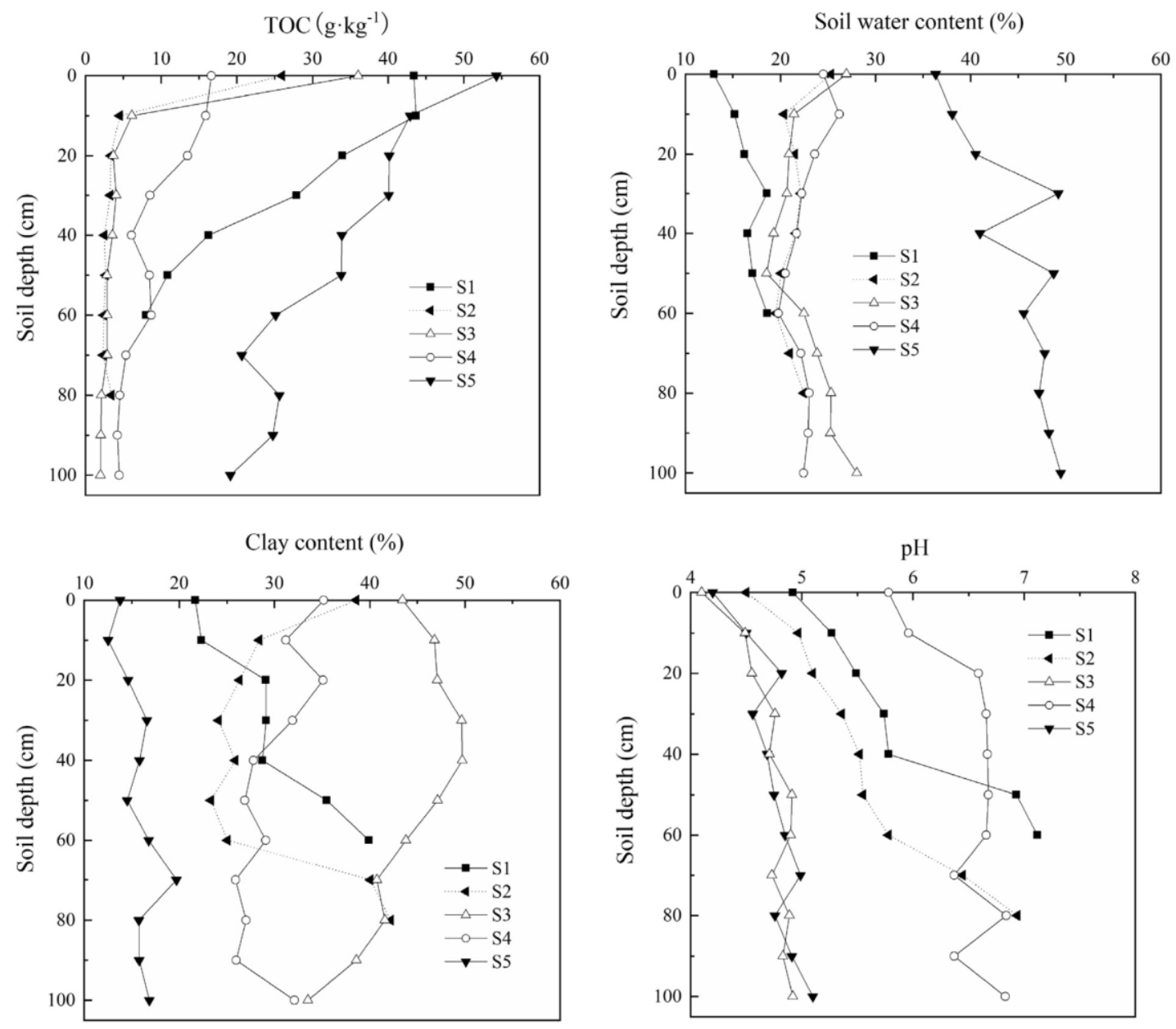

Fig. 5. Vertical distribution of soil physical-chemical indexes in the soil profiles.

\subsection{PAHs sources}

As Ant/(Ant t Phe) $<0.1$ and Fla/(Fla t Pyr) $>0.5$ (Fig. 2), PAHs in soils of the 5 sites were mainly derived from petroleum and the combustion of grass/wood/coal (Yunker et al., 2002). The ratio $\mathrm{BaA} /(\mathrm{BaA}$ t Chry) in most samples ranged from 0.1 to 0.35 (Fig. 2), further confirming a mixed source for PAHs at the 5 sites. In comparison with other PAHs, InP and $\mathrm{BgP}$ photodegrade slower with similar degradation rates (Yunker et al., 2002), and thus the ratio of $\mathrm{InP} /(\mathrm{InP} t \mathrm{BgP})$ was more accurate as an indicator for the source of PAHs. As specified by the ratio of $\mathrm{InP} /(\operatorname{InP} t \mathrm{BgP})$, the major source of PAHs at S1 S4 (sites near busy roads) was the combustion of petroleum, and grass/wood/coal, while that at S5 was the combustion of grass/wood/coal.

The isomeric ratios indicated that the combustion of grass/ wood/coal was the most important source of PAHs in the springs (Fig. 4), with exception that the ratio of Ant/(Ant + Phe) indicated the direct petroleum contamination was the primary source for PAHs from June 2011 to October 2011. However, as the ratio of Ant/ (Ant + Phe) during this period was 0.080.09 , which was close to the dividing line (0.1), it was not regarded as a strong indication, especially considering the faster photochemical transformation of Ant than Phe in the atmosphere (Fraser et al., 1998). From October 2010 to May 2011, the weather was foggy in the study area, and the photochemical decomposition of PAHs was slow and can be neglected. But after June 2011, the clear weather with strong solar irradiation obviously influenced the photochemical transformation of PAHs on the isomeric ratio. Fla and Pyr also underwent nonnegligible phototransformation during this period. However, this may not induce the marked influence on the ratio of Fla/(Fla $+\mathrm{Pyr})$, since photodegradation rates of 
the two PAHs were close (Yunker et al., 2002; Tobiszewski and Namie_snik, 2012). During the study period, coal was still the major fossil fuels used in Chongqing Municipality. Thus, it was unsurprising that the combustion of coal was the primary source of PAHs in Nanchuan, where $60 \%$ of the electricity was generated from coal power plants in 2010 (CMBS, 2011). In some areas in Europe or North America, the wood/coal combustion was a primary source of PAHs, especially in winter when the intensive space heating was needed (Christensen and Arora, 2007; Ravindra et al., 2008). But in Chongqing, a subtropical zone, the electricity consumed by using air conditioners in summer (average temperature: $31.5^{\circ} \mathrm{C}$ ) were more intensive than that used for space heating in winter (average temperature: $7.9^{\circ} \mathrm{C}$ ). Thus, the ratios indicating the combustion of grass/wood/coal were stable in summer after June, but they varied markedly before June.

\section{Conclusions}

The occurrence of 16 priority PAHs in the soils and the epikarst spring water at Nanchuan District, Chongqing was investigated from October 2010 to October 2011. Due to the thin surface soil layer and karst features in the four epikarst spring systems, the epikarst spring water was contaminated and the detection ratio and concentrations of PAHs in epikarst spring water were high. The concentrations of PAHs in top soils were primarily influenced by vegetation covers of pine litters that released PAHs continuously and slowed down the photodegradation. The soil 2-3 rings PAHs increased gradually with the increase of altitude, and they dominated the PAHs in subsoil except for that at $\mathrm{HG}$ spring catchment. The vertical migration of PAHs was mainly influenced by vegetation covers, temperature, altitude, number of rings, soil TOC and soil compaction. In particular, TOC was the key factor controlling the vertical migration of PAHs in the overlying soil in HG, LHG and BSW epikarst spring catchment, which meant that increasing TOC contents could effectively hinder the vertical migration of PAHs. At SF spring catchment, the large flux led to a homogenous vertical distribution of PAHs, and thus the influence of the soil characteristics (TOC, water contents, $\mathrm{pH}$, and clay contents) was insignificant. The main source of PAHs in the soils and springs was the combustion of grass/wood/coal, while the liquid fossil fuel combustion was a minor source. The high concentration and detection frequency of PAHs in epikarst spring waters indicate that the protection effects of karst soils for the undergroundwater were likely lost in the study area. Thus, increasing the soil TOC can reduce groundwater pollution, but most important, the development of renewable energy instead of fossil energy can protect soil and groundwater for the future pollution in this area.

In the future research, the method and mechanism used to improve the bound capacity of PAHs to soil will be conducted.

\section{Acknowledgement}

This study was supported by the National Key Research and Development Program of China (No. 2016YFC0502306 and 2016YFD0800305), the National Natural Science Foundation of China (No. 41601584 and 41761091), and Geological survey project of Ministry of Land and Resources of China (DD2060305).

\section{References}

Ball, A., Truskewycz, A., 2013. Polyaromatic hydrocarbon exposure: an ecological impact ambiguity. Environ. Sci. Pollut. Res. Int. 20, 4311-4326.

Bandowe, B.A.M., Sobocka, J., Wilcke, W., 2011. Oxygen-containing polycyclic aromatic hydrocarbons (OPAHs) in urban soils of Bratislava, Slovakia: patterns, relation to PAHs and vertical distribution. Environ. Pollut. 159, 539-549. 
Bogan, B.W., Sullivan, W.R., 2003. Physicochemical soil parameters affecting sequestration and mycobacterial biodegradation of polycyclic aromatic hydrocarbons in soil. Chemosphere 52, 1717-1726.

Chefetz, B., Deshmukh, A.P., Hatcher, P.G., 2000. Pyrene sorption by natural organic matter. Environ. Sci. Technol. 34 (14), 2925-2930.

Chen, Y.J., Feng, Y.L., Xiong, S.C., Liu, D.Y., Wang, G., Sheng, G.Y., Fu, J.M., 2011. Polycyclic aromatic hydrocarbons in the atmosphere of Shanghai, China. Environ. Monit. Assess. 172, 235-247.

Christensen, E.R., Arora, S., 2007. Source apportionment of PAHs in sediments using factor analysis by time records: application to lake Michigan, USA. Water Res. 41, 168-176.

Chrysikou, L.P., Samara, C.A., 2009. Seasonal variation of the size distribution of urban particulate matter and associated organic pollutants in the ambient air. Atmos. Environ. 43, 4557-4569.

CMBS (Chongqing Municipal Bureau of Statistics), 2011. Chongqing Statistical Yearbook (Chapter 5, 9).

Cousins, I.T., Gevao, B., Jones, K.C., 1999. Measuring and modelling the vertical distribution of semi-volatile organic compounds in soils. I: PCB and PAH soil core data. Chemosphere 39 (14), 2507-2518.

Cui, X.H., Li, B.H., Chen, H.H., 2008. Contamination characteristics and pollutant sources analysis on PAHs in shallow groundwater in suburb of Taihu plain. Envrionmental Science 29 (7), 1806-1810.

Ford, D.C., Williams, P.W., 2007. Karst Hydrogeology and Geomorphology. Wiley, Chichester, p. 562.

Fraser, M.P., Gass, G.R., Simoneit, B.R., Rasmussen, R.A., 1998. Air quality model evaluation data for organics. 5. C6-C22 non-polar and semipolararomatic compounds. Environ. Sci. Technol. 32, 1760-1770.

He, F.P., Zhang, Z.H., Wan, Y.Y., Lu, S., Wang, L., Bu, Q.W., 2009. Polycyclic aromatic hydrocarbons in soils of Beijing and Tianjin region: vertical distribution, correlation with TOC and transport mechanism. J. Environ. Sci. 21, 675-685.

Heemken, O.P., Stachel, B., Theobald, N., Wenclawiak, B.W., 2000. Temporal variability of organic micropollutants in suspended particulate matter of the river elbe at hamburg and the river mulde at dessau, Germany. Arch. Environ. Contam. Toxicol. 38 (1), 11-31.

Jiang, Y.J., Hu, Y.J., Schirmer, M., 2013. Biogeochemical controls on daily cycling of hydrochemistry and $\delta 13 \mathrm{C}$ of dissolved inorganic carbon in a karst spring-fed pool. J. Hydrol. 478, 157-168.

Knabner, P., Totsche, K.U., K€ogel-Knabner, I., 1996. The modeling of reactive solute transport with sorption to mobile and immobile sorbents. Part I: experimental evidence and model development. Water Resour. Res. 32, 1611-1622.

Kong, X.S., Luan, R.J., Miao, Y., Qi, S.H., Li, F., 2015. Polycyclic aromatic hydrocarbons in sediment cores from Dashiwei Tiankeng reach in the Bailang underground river, South China. Environ. Earth Sci. 73, 5535-5543.

Krauss, M., Wilcke, W., Zech, W., 2000. Polycyclic aromatic hydrocarbons and polychlorinated biphenyls in forest soils: depth distribution as indicator of different fate. Environ. Pollut. 110, 79-88.

Lan, J.C., Sun, Y.C., Xiao, S.Z., Yuan, D.X., 2016. Polycyclic aromatic hydrocarbon contamination in a highly vulnerable underground river system in Chongqing, Southwest China. J. Geochem. Explor. 168, 65-71. 
Levy, W., Pandelova, M., Henkelmann, B., Bernh€oft Fischer, N., Antritter, F., Schramm, K.W., 2017. Persistent organic pollutants in shallow percolated water of the Alps Karst system (Zugspitze summit, Germany). Sci. Total Environ. 579, 1269-1281.

Li, C.L., Fu, J.M., Sheng, G.Y., Bi, X.H., Hao, Y.M., Wang, X.M., Mai, B.X., 2005. Vertical distribution of PAHs in the indoor and outdoor PM2.5 in Guangzhou, China. Build. Environ. Times 40, 329-341.

Li, H.L., Chen, J.J., Wu, W., Piao, X.S., 2010. Distribution of polycyclic aromatic hydrocarbons in different size fractions of soil from a coke oven plant and its relationship to organic carbon content. J. Hazard Mater. 176, 729-734.

Li, J., Li, F.D., 2017. Polycyclic aromatic hydrocarbons in the Yellow River estuary: levels, sources and toxic potency assessment. Mar. Pollut. Bull. 116 (1-2), 479-487.

Li, L.L., 2009. Study of effects of ecological environment on regulated function of epikarst water in typical karst area of southwest, China (In Chinese). School of Geographical Sciences, Southwest University, Chongqing, pp. 47-76.

Li, W., He, J.T., Ma, W.J., Ji, Y.P., 2012. Groundwater PAHs contamination risk assessment of reclaimed wastewater irrigation area, south-east part of Beijing, China. J. Agro Environ. Sci. 31 (4), 713-720.

Liu, X., Zhang, G., Jones, K.C., Li, X.D., Peng, X.Z., Qi, S.H., 2005. Compositional fractionation of polycyclic aromatic hydrocarbons (PAHs) in mosses (Hypnum plumaeformae WILS.) from the northern slope of Nanling Mountains South China. Atmos. Environ. 39, 5490-5499.

Lu, Z., Zeng, F.G., Xue, N.D., Li, F.S., 2012. Occurrence and distribution of polycyclic aromatic hydrocarbons in organo-mineral particles of alluvial sandy soil profiles at a petroleum-contaminated site. Sci. Total Environ. 433, 50-57.

Ma, Y., Harrad, S., 2015. Spatiotemporal analysis and human exposure assessment on polycyclic aromatic hydrocarbons in indoor air, settle house dust, and diet: a review. Environ. Int. 84, 7-16.

Maruya, K.A., Risebrough, R.W., Horne, A.J., 1996. Partitioning of polynuclear aromatic hydrocarbons between sediments from San Francisco Bay and their porewater. Environ. Sci. Technol. 30, 2942-2947.

Ohura, T., Sakakibara, H., Watanabe, I., Shim, W.J., Manage, P.M., Guruge, K.S., 2015. Spatial and vertical distributions of sedimentary halogenated polycyclic aromatic hydrocarbons in moderately polluted areas of Asia. Environ. Pollut. 196, 331-340.

Oramah, I.T., Qi, S.H., Kong, X.S., Liu, H.F., Li, J., Wang, X.Q., Wang, Y.H., 2008.

Distribution of polycyclic aromatic hydrocarbons in Datuo karst Tiankeng of South China. Environ. Geochem. Health 30, 423-429.

Perrette, Y., Poulenard, J., Durand, A., Quiers, M., Malet, E., Fanget, B., Naffrechoux, E., 2013. Atmospheric sources and soil filtering of PAH content in karst seepage waters. Org. Geochem. 65, 37-45.

Perugini, M., Visciano, P., Giammarino, A., Manera, M., Di Nardo, W., Amorena, M., 2007. Polycyclic aromatic hydrocarbons in marine organisms from the Adriatic Sea, Italy. Chemosphere 66 (10), 1904-1910.

Ping, L.F., Luo, Y.M., Zhang, H.B., Li, Q.B., Wu, L.H., 2007. Distribution of polycyclic aromatic hydrocarbons in thirty typical soil profiles in the Yangtze River Delta region, east China. Environ. Pollut. 147 (2), 358-365.

Raber, B., K€ogel-Knabner, I., Stein, C., Klem, D., 1998. Partitioning of polycyclic aromatic hydrocarbons to dissolved organic matter from different soils. Chemosphere 36 (1), 79-97. 
Ravindra, K., Wauters, E., Grieken, R.V., 2008. Variation in particulate PAHs levels and their relation with the transboundary movement of the air masses. Sci. Total Environ. 396, 100110 .

Schwarz, K., Gocht, T., Grathwohl, P., 2011. Transport of polycyclic aromatic hydrocarbons in highly vulnerable karst systems. Environ. Pollut. 159, 133-139.

Shao, Y.X., Wang, Y.X., Xu, X.Q., Wu, X., Jiang, Z., He, S.S., Qian, K., 2014. Occurrence and source apportionment of PAHs in highly vulnerable karst system. Sci. Total Environ. 490, 153-160.

Shevenell, L., McCarthy, J.F., 2002. Effects of precipitation events on colloids in a karst aquifer. J. Hydrol. 255, 50-68.

Soren, T., Gerhard, W.B., 2002. Bioformation of polycyclic aromatic hydrocarbons in soil under oxygen deficient conditions. Soil Biol. Biochem. 34 (5), 733-735.

Tian, X.X., Liu, J.X., Zhou, G.Y., Peng, P.A., Wang, X.L., Wang, C.L., 2008. Estimation of the annual scavenged amount of polycyclic aromatic hydrocarbons by forests in the Pearl River Delta of Southern China. Environ. Pollut. 156, 306-315.

Tobiszewski, M., Namie_snik, J., 2012. PAH diagnostic ratios for the identification of pollution emission sources. Environ. Pollut. 162 (1), 110-119.

Wang, X.C., Zhang, Y.X., Chen, R.F., 2001. Distribution and partitioning of polycyclic aromatic hydrocarbons (PAHs) in different size fractions in sediments from Boston harbor, United States. Mar. Pollut. Bull. 42, 1139-1149.

Weigand, H., Totsche, K.U., Knahner, I.K., 1998. Effect of fluctuating input of dissolved organic matter on long-term mobility of polycyclic aromatic hydrocarbons in soils. Phys. Chem. Earth 23 (2), 211-214.

Yang, R., Liu, Z.H., Zeng, C., Zhao, M., 2012. Response of epikarst hydrochemical changes to soil CO2 and weather conditions at Chenqi, Puding, SW China. J. Hydrol. 468-469, 151158.

Yuan, D.X., Zhu, D.H., Weng, J.T., Zhu, X.W., 1994. Karst of China (In Chinese). Geological Publishing House, Beijing, p. 1 (in Chineses).

Yuan, D.X., 2000. Aspects on the new round land and resources survey in karst rock desertification areas of South China. Carsol. Sin./Zhong Guo Yan Rong 19 (2), 103-108 (in Chinese).

Yunker, M.B., Macdonald, R.W., Vingarzan, R., Mitchell, R.H., Goyette, D., Sylvestre, S., 2002. PAHs in the Fraser River basin: a critical appraisal of PAH ratios as indicators of PAH source and composition. Org. Geochem. 33, 489-515.

Zhang, H.B., Luo, Y.M., Wong, M.H., Zhao, Q.G., Zhang, G.L., 2006. Distributions and concentrations of PAHs in Hong Kong soils. Environ. Pollut. 141, 107-114. 